\title{
Managing Underwater Heritage in Egypt
}

\author{
Ahmed Motawea Hussein Shaikhon \\ Archaeologist at the Egyptian Ministry of Tourism and Antiquities \\ Ph.D. Candidate Heritage and museum studies, Helwan University \\ E-mail: ahmed_motawea83@yahoo.com
}

\begin{abstract}
:
The protection and management of Underwater Cultural Heritage is a challenging topic, as it involves the interplay of national and international law, This study will present information about underwater heritage in Egypt and the most important discoveries, the legal framework for the protection of underwater heritage at the international and local level as well as the management of waterlogged heritage in Egypt and emphasize the importance of strategic planning function - the key to all of the follows in site management. It helps to organize the program, identify key issues and anticipate questions, and provide the data to answer these questions. Egypt has a sunken archaeological treasure that is one of the largest sunken archaeological sites in the world and the protection and management of Underwater Cultural Heritage is a challenging topic, as it involves the interplay of national and international law this paper aims to shed light on the Underwater Cultural Heritage management in Egypt.
\end{abstract}

Keywords: Underwater Heritage - Mediterranean Sea - Red Sea - Sunken - Maritime 


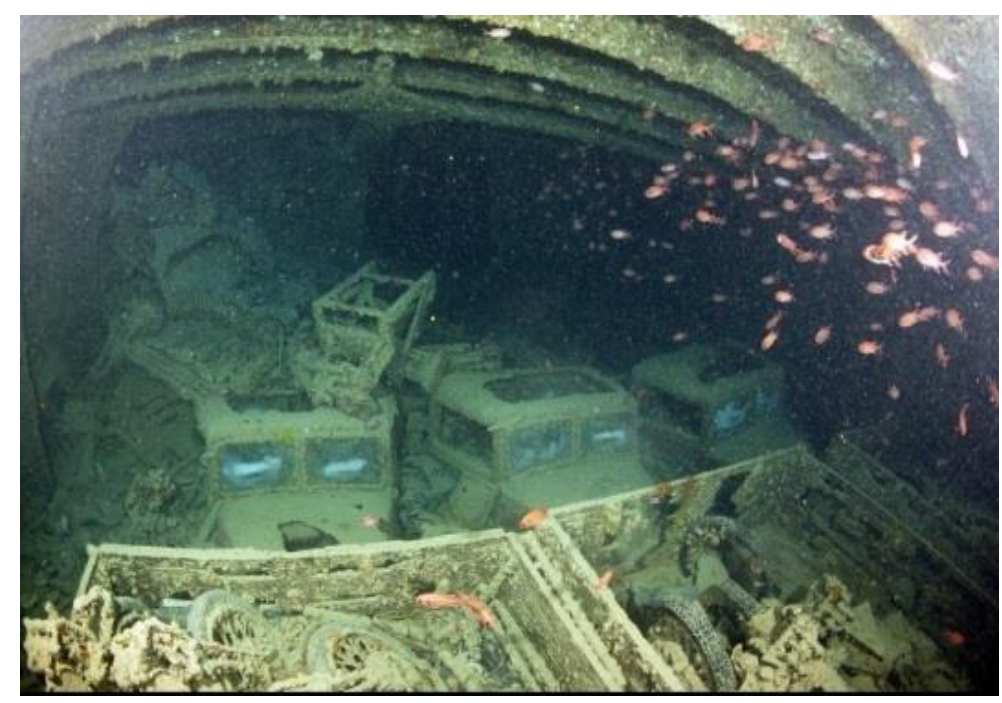

The SS Thistlegorm near Ras Muhammad in the Red Sea

\section{Introduction:}

Egypt is bathed by two seas, the Mediterranean to the north and the Red Sea to the east is crossed by the famous Nile and is inlaid with several lakes and lagoons, which explains the richness and the importance of its underwater cultural heritage, Egypt has a sunken archaeological treasure that is one of the largest sunken archaeological sites in the world, including the city of Canopus, the Great Temple of Serapis, Heracleum, the Great Temple of Amun in Abu Qir, as well as shipwrecks and many parts of Pharaonic temples in Alexandria and also in the Red Sea is one of the most important repositories of the marine biodiversity in the world (Ormond et al., 1987) has a sunken archaeological treasure which led to the Sadana Island Shipwreck Excavation.

Nowadays, underwater archaeological research is a highly technical task that must answer the requirements of historical research a major cultural sensibility should be taught to the divers that want to exploit the happiness of a dive in a beautiful sea. In order to avoid illegal activity against cultural underwater heritage, we have to fight in different fields. Educative programs must be addressed mainly to those people that have close connections with sea activity such as charters and diving companies, as well as 
clubs and associations. Those are the best guards of the cultural underwater heritage because it is on this field that they can optimize and increase their commercial offer.

\title{
Definition of underwater cultural heritage:
}

Generally speaking, underwater cultural heritage and shipwrecks are considered synonyms. However, this interpretation presents two main limits. First, it is underinclusive: the underwater cultural heritage includes different typologies of sites other than shipwrecks (such as sunken cities, venerated sites, ancient harbors, prehistoric landscapes, fish traps, etc.). Second, it is simultaneously over-inclusive: not all the shipwrecks are considered part of the underwater cultural heritage (for example, contemporary shipwreck sites are generally excluded). Therefore, defining the underwater cultural heritage requires the identification of one or more shared features among assets that are (or have been for a certain period) in an underwater environment (Unesco2001).

\begin{abstract}
“The terms 'underwater', 'culture', and 'heritage' are individually susceptible to various interpretations that are made no easier by their amalgamation. In particular, the term 'culture' is an all-embracing term that applies to every aspect of contemporary society".
\end{abstract}

(Forrest, 2002)

\section{History of underwater Heritage in Alexandria:}

In 1909 submerged port installations were discovered at Dekhela and in the following year, some marine constructions were found near the entrance to the Western Harbour to the west of Anfoushy Bay. In 1933, the accident again played a role in the discovery of a second underwater site, when a British Royal Air Force pilot saw many submerged ruins from his plane while flying over Abu-Qir Bay east of Alexandria. Prince Omar Toulson, a member of the Royal Archaeological Society in Alexandria, funded research that led to the recovery of a larger-than-life-sized white marble head of Alexander the Great (Khalil, 2010) while in the 1960s \& 1970s Kamel Abu el-Saadat made a series of important discoveries in the areas of the Eastern Harbour, Qaitbay, Aboukir and also 
along the north coast. In the 1980s this pioneer of underwater archaeology was to the fore in the search for the sunken fleet of Bonaparte (Abd el Muiged 2010).

The activity on underwater cultural heritage was undertaken in Egypt for one hundred years, the Department for Underwater Antiquities (DUA) was founded in late 1996. The necessity for such an organization appeared after the discovery of the submerged remains of Alexandria Lighthouse at the foot of the "Qaitbay" fort and the rediscovery of a part of the royal quarter in the Eastern Harbor in 1994 and 1996 respectively.

Since 1996 the DUA has supervised many archaeological surveys and excavations in its territorial and internal waters. These geophysics and visual archaeological surveys and underwater excavations were conducted by Egyptian and foreign institutions. An archaeologist from Egypt, Europe, and the USA took part in the discoveries and the studies of different sites under the waters of the Mediterranean Sea, the Red Sea, the Nile, Lake Quarun, on the island of Nelson, and around Lake Mareotis. These discoveries cover the Pharaonic, Hellenistic, roman, byzantine, and Islamic periods (Abd el Muiged 2010).

In November 2017 the Supreme Council of Antiquities announced the discovery of three shipwrecks dating back to the Roman era, during excavation works carried out by the Egyptian mission in collaboration with the European Institute of Underwater Archeology in the Eastern port of Alexandria.

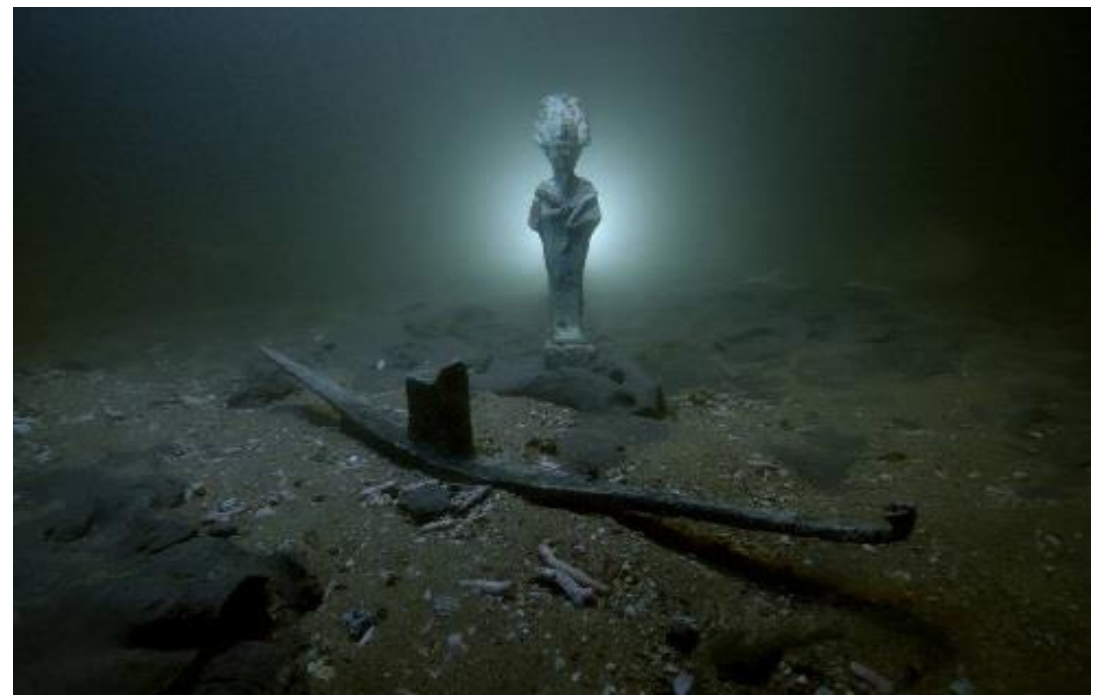


Fig (1) votive bark of god Osiris about $30 \mathrm{~cm}$ wide and about $5 \mathrm{~cm}$ wide.

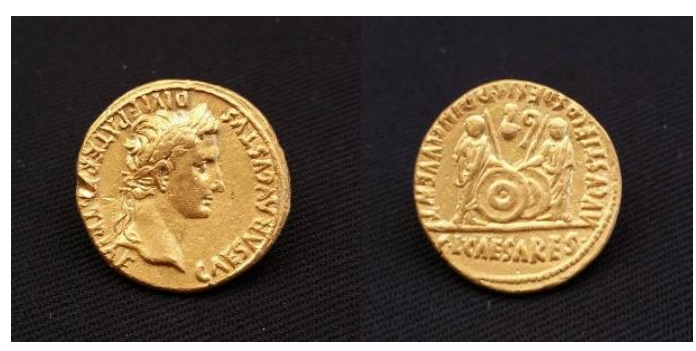

Fig (2) gold coins dating back to the Emperor "Octavius".

and the mission has succeeded in uncovered also a royal head carved in crystal dating back to the Roman-era and probably it belongs to the commander of the armies "Antonio", in addition to three gold coins dating back to the Emperor "Octavius" Fig (2) in Abu Qir Bay in Alexandria .also uncovered a votive bark of god Osiris at the Heraklion sunken city in Abu Qir bay Fig (1).

\section{Underwater Heritage in the Red Sea:}

The Red Sea is one of the most important repositories of marine biodiversity in the world (Ormond et al., 1987). The Institute of Nautical Archaeology (INA-Egypt) started its first project, a coastal survey of the Red Sea in 1994, which led to the Sadana Island Shipwreck Excavation. The SS Thistlegorm was a British armed Merchant Navy ship built in 1940 by Joseph Thompson \& Son in Sunderland, England. It was sunk on 6 October 1941 near Ras Muhammad in the Red Sea and it's now a well-known diving site resting at thirty meters below sea level on a sandy bed (Merchant, 2012).

The Times named the SS Thistlegorm as one of the top 10 wreck diving sites in the world. SS Thistlegorm is accessible to most divers and the destruction of a large section of its superstructure makes for novel routes of exploration It illustrates that 
INTERNATIONAL JOURNAL OF

MULTIDISCIPLINARY STUDIES IN ARCHITECTURE

AND CULTURAL HERITAGE

objects/vessels/buildings have natural as well as social lives. SS Thistlegorm is currently becoming re-humanized by dive tourism Fig (3).
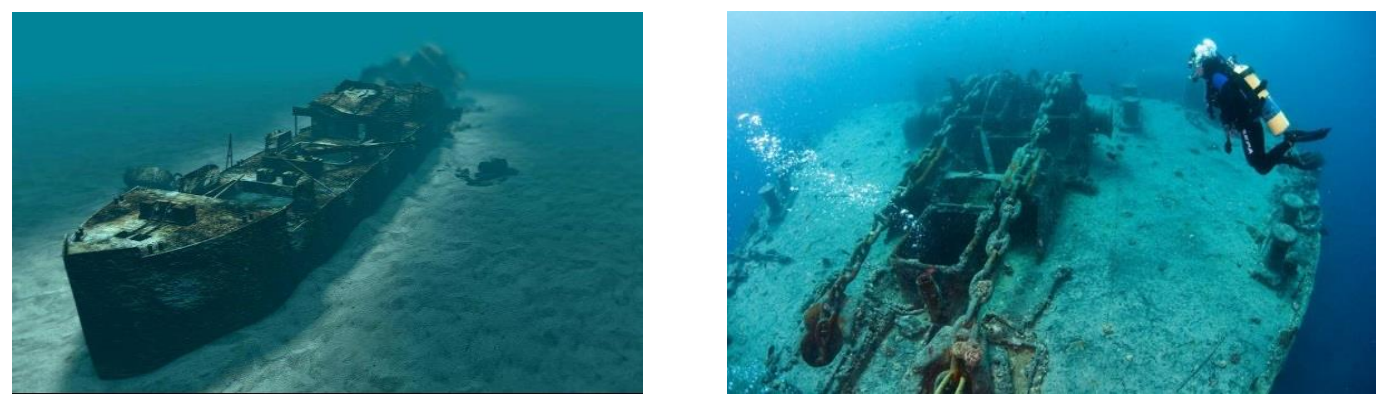

Fig (3) The SS Thistlegorm near Ras Muhammad in the Red Sea

\section{Sadana Island Shipwreck Excavation:}

in 1994, the INA-Egypt-SCA Red Sea Shipwreck Survey located an Ottoman-period vessel off Sadana Island near Safaga, about $40 \mathrm{~km}$ south of Hurghada, and excavated the wreck during the 1995, 1996, and 1998 seasons. Sport divers in the Red Sea have known of the shipwreck for more than 10 years, and some reported that the wreck was being looted. INA-Egypt decided to excavate the wreck to protect the information that was being lost and to draw attention to its importance to the Egyptian authorities.
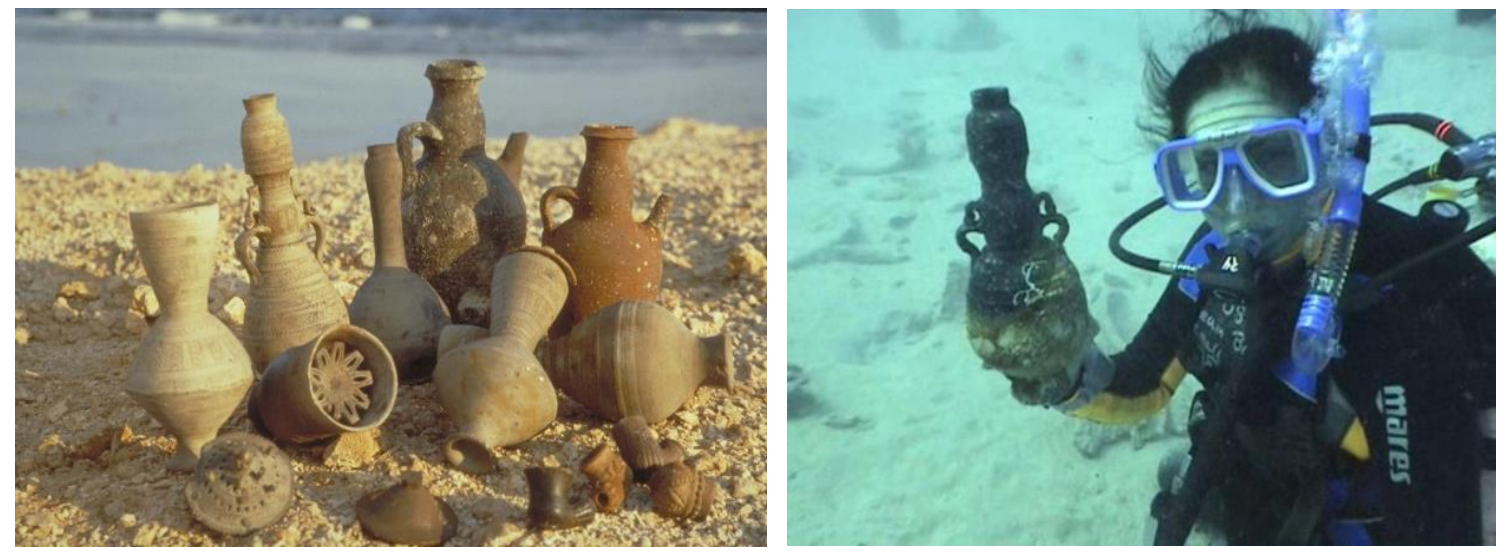

Fig (4) Artifacts found on Sadana wreck

https://en.unesco.org/silkroad/silk-road-themes/underwater-heritage/sadana-islands-shipwreck

The Sadana Island Shipwreck Excavation also provided an opportunity to train archaeology students and ministry of Antiquities inspectors from the nascent of the 
Department for Underwater Antiquities (DUA) on the aspects and techniques of nautical archaeology. The excavation's primary goals were to remove visible, portable, and attractive objects to discourage looting, to document the ship's structure, and to address questions related to the number of objects of various classes, Fig (4) their stowage, and the ship's origin. All excavated objects have been transferred to the Alexandria Conservation Laboratory for Submerged Antiquities in the National Maritime Museum (Haldane, 1994).

\section{Management of the underwater cultural heritage:}

The Management Plan for a particular site is a working document that is updated periodically. Because its arrangement and complexity must be tailored to the needs of the site, generic models may be suggestive but not prescriptive. Each site needs its customized plan.

There are many practical considerations in designing MPAs that are to be addressed during the planning phase: location of MPA facilities; types of boats and motors for surveillance and transport; boundary demarcations; zoning of activities to separate incompatible uses where necessary; recruiting and training of staff; the development schedule and budgets; analysis of visitor use compatibility and safety considerations; conflict resolution and cooperative arrangements with local communities and industries; and such environmental factors as the types of habitats to include, and the size of the protected area and its different zones. Also, there should be consideration of external impacts on the site and procedures to minimize these effects. Scientific research: it concerns the possibility of investigating the site in order to discover new information.

Conservation: To avoid the destruction and degradation of the underwater cultural heritage in order to keep it available for current and future generations.

Protection: to prevent and defend the underwater cultural heritage from the risk of being looted, destroyed or damaged by voluntary or accidental human activities in order to keep it available for current and future generations. Donald H. Keith clarified that 
"conservation is the practice of cleaning and stabilizing artifacts using a set of specialized techniques” (Ruppe and Barstad, 2002).

Preservation: To maintain the underwater cultural heritage untouched in its context and a method of management. It is "based on the recognition of the importance of the interplay between the site, its story, and its context" (UNESCO, 2011).

Access: To create the conditions for the enjoyment of the underwater cultural heritage by the general public. Positively, open access to the sites raises visitors' awareness of the importance and appeal of the underwater cultural heritage.

Promotion: To create awareness and understanding of the underwater cultural heritage. Through different media: books, articles, brochures, waterproof information sheets, panels, documentaries, conferences, events, websites, forums, social networks, and databases.

Socio-Economic Impact: it aims, as a whole, to consider the social effects and the monetary costs-benefits that are generated, directly and indirectly, by the management of the underwater cultural heritage, the socio-economic impact interest is based on three different elements (involvement of the local community- a spread of knowledge-direct and indirect economic impact).

\section{Managing Underwater Cultural Heritage:}

Oxley and Gregory noted that site management as a professional expression is not equal to preservation but also needs to draw the best ways of controlling and, mitigating the effects of surrounding dangerous impacts. Donald H. Keith clarified that Heritage sites are entirely so dynamic, consequently, the management process must recognize the degradation progress that led to archaeological remains to gradually alter or recess. Strategically, he indicated that management could be concentrated on estimating the micro-and macro impacts to apply the process of heritage impact assessment, either environmental impact or human-induced impact assessments, attempting to find out the 
potential solutions mitigating these changes especially bio-deterioration and corrosion of artifacts. Then, he asserted the significance of the auditing process to ensure the conservation statement of the submerged heritage site (Ruppe \& Barstad, 2002).

With regard to material, shipwreck remains, preservation should be the primary objective of salvage. The physical frailty of $\mathrm{UCH}$ requires ad hoc consideration. Terrestrial management models cannot simply be imposed on marine archaeological sites. The physical environment, the impossibility of monitoring a site on a constant basis, and the risk of destruction by tides and human activities all create an entirely different setting. The creed of preservation in situ is extremely problematic underwater. (Ransley 2006).

Furthermore, as Jesse Ransley asks, "Considering that divers are only a small, and relatively wealthy, section of the public, should diver access be a priority over other forms of public interpretation above the water?" (Ransley 2006) If recovering and displaying a wreck is not possible, its cargo should be recovered. Museums ensure better preservation and security schemes and allow access to the elderly and disabled members of a population (Vadi 2016).

From a legal perspective, discourse on cultural heritage should focus more on governance than on ownership. Traditionally, salvage law attributes the property of maritime remains to the state; the salvor has mere possession rights. (Bederman 2000) Still, it may be argued that states should not be considered owners but rather guardians or custodians of these cultural goods. In other words, while the traditional concept of property involves the power to use or destroy a certain thing, custodianship denotes certain duties (Vadi 2016).

\section{Underwater Culture Heritage Education:}

On the academic level, no nautical archaeology program exists at an Egyptian university so far, but the Archaeology Department of the University of Alexandria has shown great interest in cooperating with foreign missions offering field training in marine archaeology to its students. The university plans to offer an undergraduate level 
introductory course in marine archaeology and will require qualified Egyptian scholars to teach the course (Khalil, 2008).

\section{International laws and interpretative perspectives related to the underwater cultural heritage:}

Underwater Cultural heritage is being addressed by convention and several charters and it is clear that its consideration within decision-making processes is progressively becoming a real challenge, both for developers and public authorities. International organizations such as United Nations Economic, Social, and Cultural Organization (UNESCO) and International Council on Monuments and Sites (ICOMOS) have set out important conservation principles and standards in the underwater cultural heritage field. As statements and guidelines for underwater conservation and management, the charters and conventions have helped to underpin national and international heritage conservation procedures.

At the international law level, the 1982 United Nations Convention on the Law of the Sea (UNCLOS) governs virtually all aspects of the law of the sea (prows 2006) but still only marginally addresses UCH. Although the UNCLOS recognizes the obligation of states to protect archaeological and historical objects, it includes only two provisions, Article 149 and Article 303, that specifically refer to such objects and establishing an obligation to protect them.

The 2001 UNESCO Convention on the Protection of underwater cultural heritage represents an international response to the concern of looting and destruction of Underwater Heritage by treasure hunters and others. The 2001 UNESCO Convention is based on four main principles and should be understood as the bar from which the gap in Egypt Underwater Heritage protection should be measured:

1. The obligation to preserve underwater cultural heritage;

2. In situ preservation policy and scientific rules for research \& recovery;

3. No commercial exploitation of this heritage;

4. Cooperation among States to protect this heritage, particularly for training, education, and outreach. 
The primary goal of the 2001 UNESCO Convention is to protect Underwater Heritage, defined as all traces of human existence having a cultural, historical or archaeological character which has been partially or totally underwater, periodically or continuously, for at least 100 years such as . . . vessels, aircraft, other vehicles or any part thereof, their cargo or other contents, together with their archaeological and natural context. The 2001 UNESCO Convention seeks to accomplish this protection through control of activities that may directly or incidentally harm Underwater Culture Heritage, and by authorizing (permitting) activities directed at Underwater Culture Heritage only when done in accordance with professional archaeological standards and practices outlined in the Annex Rules. The geographic scope of the 2001 UNESCO Convention includes Underwater Culture Heritage located in all maritime zones, as well as the continental shelf and seabed Area beyond national jurisdiction.

\section{The ICOMOS International Committee on the Underwater Cultural Heritage (ICUCH).}

This Charter is intended to encourage the protection and management of underwater cultural heritage in inland and inshore waters, in shallow seas, and the deep oceans. It focuses on the specific attributes and circumstances of cultural heritage underwater and should be understood as a supplement to the ICOMOS Charter for the Protection and Management of Archaeological Heritage, 1990.

\section{National law:}

The Antiquities' protection law (Law No. 117 of 1983 amended with the law No 3-61 of 2010) was issued to supersede law No. 215, issued in 1951, and all other previous texts that contradict its articles. The first two articles define the antiquities and their sites and placements. Article 5 indicates the organizing authority (Ministry of Antiquities). Article 6 considers antiquities as being commonwealth with some exceptions. Where articles $31 \& 32$ care about the administrative and scientific organization of the archaeological activities (Abd-el Maguid, 2010).

Abd el- Maguid notes that the Egyptian law is in accordance with the UNESCO chart and that the lawmakers were aware of the protection of the underwater cultural heritage whether in inland water territorial water. But the main issue is not the deficiency of the law but the application of this one. Although the law on antiquities mentions that all the 
restrictions are applicable on the antiquity found on or in the land like in water, it remains always a problem to guard a discovered and registered site even if the coastguards prohibit the diving in this site. The increasing number of sites and their distance makes the mission impossible.

\section{Underwater objects:}

If the preservation in situ is not considered an option available (for reasons of protection, enhancement, or scientific investigation), the artifacts can be recovered and, after the proper conservative treatments, they can be stored or exhibited in an "on-land" museum. In recent years, underwater cultural heritage has attracted increasing attention from both the scientific community and the general public. To scientists, it represents an invaluable source of information on ancient civilizations and historic seafaring. To the public at large, it offers an opportunity to further develop leisure diving and tourism. Many important museum's exhibit objects recovered from underwater ruins or shipwrecks, more than 5000 objects from underwater in Alexandria Weights ranged from $100 \mathrm{~kg}$ to 75 tons (Abd-el Maguid, 2010). Forty pieces were raised and conserved and are now exhibited in the Roman Theater in Alexandria while a lot of objects distribute between the National Museum of Alexandria, bibliotheca Alexandria museum, and three storage at the Department for Underwater Antiquities. Some even exhibit whole wrecks.

An international exhibition entitled "Egypt's Sunken Treasures" was held in some countries and was dedicated to the discoveries of Alexandria. The exhibition presented objects exclusively from the underwater excavations of the Institut Européen d'Archéologie Sous-Marine (IEASM), conducted in 1992 in Alexandria and Abukir Bay by Franck Goddio in co-operation with the Ministry of Antiquities in Egypt. Around 500 artifacts were on view, most of them never before shown in public. Among the impressive finds were 5 meters high statues of a king and queen, as well as statues of sphinxes, offerings and liturgical objects, steals, jewelry and coins, ceramics, and items from everyday life of ancient Egypt. (Goddio). On the other hand, Goddio presents that it was an immense success, demonstrating the vast international interest in these extraordinary findings. After Berlin, Paris, Bonn, and Madrid, this exhibition 
went to Turin and then Yokohama in Japan. It was seen by almost 3 million visitors, making it one of the most noted exhibitions in recent years. The income generated was considerable, and a portion was allocated to contribute to a planned underwater museum in Alexandria USD 1.6 million (Goddio).

\section{Maritime Museum:}

The idea of making Alexandria's Eastern Harbour and the area around the Citadel into a Maritime museum was first proposed by Selim Morcos (1965). The proposal to build an underwater museum in Alexandria to accommodate the finds from Alexandria's harbour and in Abukir was greeted with much enthusiasm in the city, as it would provide the ideal reviving element to attract tourists who usually opt for visits to Giza and Sharm El Sheikh. It would also attract cruise and yachting tourism from the Mediterranean - as reiterated by an expert recommendation made at a UNESCO meeting in Alexandria in 2006. Setting up of National Maritime Museum in "Alexandria" was proposed, specifically at the foot of Qaitbay Fortress in the Eastern Harbor, exploring and conserving Egyptian underwater cultural heritage in-situ (Abdel Maguid, 2012).

The creation of the museum would lead to direct benefits in terms of employment (for instance in the construction industry) and upon completion, these benefits are expected to continue thanks to the jobs created for the operation and maintenance of the museum. A project of this scale is also expected to generate indirect benefits in terms of consumption through various services, with the restaurants, hotels, transport, construction, and maintenance necessary for a rich tourism environment to flourish. Additionally, an indirect effect is an investment from other organizations and businesses in the development of the neighborhoods of the museum through the development of hotels, services, infrastructure, entertainment, cruises, guided tours, and weekends organized to combine Alexandria, northeast, and west coasts to Alamein(UNESCO,2001).

Maritime Museum designed in dual nature, inland and underwater, breaking down the traditional form of a museum, following the UNESCO 2001 Convention in order to preserve this heritage in-situ against a group of both environmental and human-induced impacts guaranteeing the conservation state of the underwater archaeological site 
(Donahue, 2015; UNESCO, 2001, p. 9), Unfortunately, until now no museum has yet been built, for finance-related issues, Egyptian Ministry of Antiquities paused going further with the underwater museum. Abd-el -Maguid suggests reactivating the decision of allowing the paid diving visits that since 2001, there are two locations that were opened by the General Department of Underwater Archaeology, SCA, for diving tourism representing Egyptian underwater cultural heritage. (Abd-el Maguid, 2012, p. 204).

\section{Conclusion:}

Underwater cultural heritage holds vast potential for scientific research and education, Shipwrecks provide vital information on past cultural exchanges, trade, and mutual influences, while sunken cities, dwellings, and religious sites reveal important data. Submerged sites are of crucial importance for understanding the development of human civilization. Public access to underwater archaeology, in the form of museums or dive trails, ensures the protection and preservation of the underwater cultural heritage concerned while promising a lasting financial return. Additionally, it stimulates local pride and instigates an increase in consideration for heritage. This paper concludes management for the underwater cultural heritage. Considering the scarce resources (financial, technical, human, etc.) available, the high costs for operating in submerged contexts, and the desire to efficiently and efficaciously protect and enhance this heritage, it is extremely important to consciously choose the right method of management for each site. 


\section{Bibliography:}

- Abd El-Maguid M. (2001): "Underwater Archaeology in Egypt in a Century", in proceedings of the 2nd Scientific Meeting of the Arabs Archaeologists, Cairo, (in Arabic). Abd-el -Maguid, M. M. (2010). Egypt, National Report on Underwater Cultural Heritage (UNESCO Regional Meeting No. CLT/CIH/MCO/2010/RP/171). Istanbul: UNESCO the Protection of Underwater Cultural Heritage. Retrieved from http://unesdoc.unesco.org/images/0018/001899/189962E.pdf

- Abd-el -Maguid, M. M. (2012). Underwater Archaeology in Egypt and the Protection of its Underwater Cultural Heritage. Journal of Maritime Archaeology, 7(1), 193 - 207.

Bossone, A. (2008). Underwater Museum Planned for Egypt's Alexandria. National Geographic News.

- David J. Bederman, Rethinking the Legal Status of Sunken Warships, 31 Ocean DEV. \& INT'L L. 97, 101 (2000). \{VOL. 42.'853\}

Donahue, M. Z. (2015). An Underwater Museum in Egypt Could Bring Thousands of Sunken Relics into View [Website]. Retrieved November 9, 2016, from http://www.smithsonianmag.com/innovation/underwater-museum-egypt-could-bringthousands-sunken-relics-into-view-180957645/?no-ist

- Forrest C. J. S., "Defining 'underwater cultural heritage'", International Journal of Nautical Archaeology, Vol. 31, N. 1, 2002, p. 3.

- Goddio, F. (n.d.). Sunken Civilization, Thonis-Heracleion: From Legend to Reality [Website]., from http://www.franckgoddio.org/projects/sunkencivilizations/heracleion.html 
- Goddio, F.: $\quad$ www.franckgoddio.org/events/temporary-exhibitions/egypts-sunkentreasures.html.

- Hassan, K. (2015). Egypt Holds its Breath for Development of Underwater Museum. AlMonitor. Retrieved from http://www.al-monitor.com/egypt-project-underwatermuseum.html

- Jesse Ransley, (2006) Rigorous Reasoning, Reflexive Research and the Space for Alternative Archaeology, 36 INT'L J. Nautical Archaeology 221, 224.

- Law no. 117 of 1983 on the Egyptian Protection of Antiquities.

- Mostafa, M. H., Grimal, N., \& Nakashima, D. (2000). Underwater Archaeology and Coastal Management: Focus on Alexandria. Paris, France: UNESCO. Retrieved from http://unesdoc.unesco.org/images/0011/001197/119751eb.pdf

- Mount, H. (2016). Treasures of Egypt's Atlantis: Raised from the Deep after 1,300 years - and Now on Dazzling Show in the British Museum. Daily Mail Online. Retrieved from www.dailymail.co.uk/news/article-3595708/Treasures-Egypt-s-Atlantis-Raised-deep-1300-years-dazzling-British-Museum.html

- $\quad$ Ormond, R. F. G., and A. J. Edwards. "Red Sea fishes." Red Sea (1987): 251-287.

- Peter Prows, Tough Love (2006): The Dramatic Birth and Looming Demise of UNCLOS Property Law (and What Is To Be Done About It) 1 (N.Y. Univ. Sch. of Law Pub. Law \& Legal Theory Research Paper Series.

- Ruppe, C. V., \& Barstad, J. F. (Eds.). (2002). International Handbook of Underwater Archaeology. New York: Springer US. Retrieved from http://link.springer.com/book.

- Sadana Islands shipwreck | SILK ROAD https://en.unesco.org/silkroad/silk-roadthemes/underwater-heritage/sadana-islands-shipwreck

- Smith, L. (2015). Theorizing Museum and Heritage Visiting. In A. Witcomb \& K. Message (Eds.), the International Handbooks of Museum Studies: Museum Theory (1st ed., Vol. 1). Chichester, West Sussex: John Wiley \& Sons, Ltd.

- Stephanie N. Merchant(2012): Submarine Geographies: the body, the senses and the mediation of tourist experience, University of Exeter, P.168

UNESCO (2001) Convention on the Protection of the Underwater Cultural Heritage, the Protection of the Underwater Cultural Heritage. 
- UNESCO Annex rules are derived from the International Charter on the Protection and Management of Underwater Cultural Heritage, a non-binding predecessor charter to the 2001 UNESCO agreement adopted by the International Council on Monuments and Sites in 1996. (The ICOMOS International Committee on the Underwater Cultural Heritage (ICUCH), ICUCH.ICOMOS.ORG,http://icuch.icomos.org/the-icomos-internationalcommittee-on-the-underwater-cultural-heritage/

- United Nations Convention on the Law of the Sea, Dec. 10, 1982, 1833 U.N.T.S. 397 [hereinafter UNCLOS]. "As of February 1, 2008, 155 states have ratified, acceded to, or succeeded to, the UNCLOS." Permanent Court of Arbitration, Ad Hoc Arbitration Under Annex VII of the United Nations Convention on the Law of the Sea, http://www.pcacpa.org/showpage.asp?pag-id=1288 (last visited January. 21, 2018).

- Valentina Sara Vadi, (2016) Investing in Culture: Underwater Cultural Heritage and International Investment Law, UNESCO Conference IKUWA 3, p. 989-999.

- Othman, Sayed, Abuelfadl, Sunken Cities: Underwater Culture Heritage of Alexandria at Abukir Bay, International Journal of Multidisciplinary Studies in Architecture and Cultural Heritage, Vol.3, No.2, 2020, pp. 95-105. 